Весна 3. Дицков ${ }^{*}$

Универзитет у Београду

Филолошки факултет https://doi.org/10.18485/analiff.2020.32.1.9

821.134.2(862)-31.09 Гарсија Маркес Г, Originalni naučni rad Primljen: 10.03 .2020 .

Prihvaćen: 22.07.2020.

\title{
ПРЕВОДНА РЕЦЕПЦИЈА ПРИПОВЕДАКА ГАБРИЈЕЛА ГАРСИЈА МАРКЕСА НА СРПСКОМ ЈЕЗИКУ: ПОСЕБНА ИЗДАҢА
}

\begin{abstract}
Овај рад се бави присуством приповедака колумбијског писца Габријела Гарсија Маркеса у српској преводној књижевности XX и XXI века. У циљу свеобухватног сагледавања релевантних параметара и учесника поменутог рецепционистичког процеса, истражује се корпус који чине посебна издања у целости посвећена преводима Гарсија Маркесових приповедака на српски језик, док преводи објављивани у периодичним публикацијама и антологијама приповедака разних аутора неће бити овом приликом предмет нашег интересовања, као ни филолошка анализа и тумачење разматраних преведених творевина. Посебна пажња поклања се утицају превода Гарсија Маркесових приповедака на уобличавање хоризонта очекивања наших читалаца у односу на пријем магичног реализма и савремене хиспаноамеричке књижевности у Србији.
\end{abstract}

Кључне речи: Габријел Гарсија Маркес, приповетке, преводи, колумбијска књижевност, хиспаноамеричка књижевност, рецепција.

\section{1. Увод}

Колумбијски писац Габријел Гарсија Маркес (Gabriel García Márquez, 1927-2014) започео је бављење књижевношћу писањем приповедака још као двадесетогодишњи студент права у Боготи. Током раздобља од скоро пола века, односно од објављивања прве приповетке ("La tercera resignación", 1947) до изласка из штампе последње збирке прича (Doce cuentos peregrinos, 1992), Гарсија Маркес је створио богат приповедачки опус, који је иновативним приказивањем фабуле као проширеног дискурса стварности, означио прекретницу у развоју ове кратке прозне врсте на хиспаноамеричком тлу (Vásquez).

Филолошки факултет, Студентски трг 3, 11000 Београд; vesna.dickov@fil.bg.ac.rs 
Градећи унутарњи монолог по угледу на Вилијама Фокнера (William Faulkner), са барокним стилом сродним шпанском пикарском роману, који одликује, са једне стране, раблеовска хиперболичност а, са друге стране, једноставност традиционалног усменог причања, Гарсија Маркес је у својим приповеткама створио свет у којем се сједињавају кафкијанска фантастика, богатство мотива из усменог предања и фрагменти географске и социјалне стварности карипског подручја (Pavlović-Samurović, 1993: 420). Многе теме, ликови, стилске особености и елементи приповедачке технике, антиципирани у приповеткама овог аутора, развили су се у потпуности тек у његовим романима, захваљујући којима су доживели темељну критичку валоризацију, као и одјек код широке читалачке публике широм света (Дицков, 2016: 205).

Предмет нашег интересовања у овом раду су преводи Гарсија Маркесових приповедака који су објављени на српском језику у облику посебних издања посвећених искључиво приповедачком стваралаштву овог хиспаноамеричког аутора. Уз примену хронолошког принципа, настојаћемо да критички представимо дате преводе са рецепционистичке тачке гледишта, анализирајући све битне параметре (опремљеност предговором и/или поговором, постојећа издања, одштампани тиражи) који одликују српске верзије збирки Гарсија Маркесових приповедака, у циљу сагледавања њиховог утицаја на формирање хоризонта очекивања наших читалаца. Филолошка анализа превода Гарсија Маркесових приповедака штампаних у поменутим посебним издањима, као и преводи приповедака Габријела Гарсија Маркеса који су објављивани у српским периодичним публикацијама, због обимности грађе и специфичних методолошких приступа, превазилазе обим овог рада и не представљају предмет нашег истраживања.

\section{2. Гарсија Маркесове приповетке у преводу на српски језик: посебна издања}

\subsection{Neverovatna i tužna istorija nevine Erendire}

i njene bezdušne babe

Прва збирка Гарсија Маркесових приповедака, представљена читаоцима са српског језичког подручја, била је збирка Neverovatna i tužna istorija nevine Erendire i njene bezdušne babe, коју је у преводу 
са шпанског језика Јасне Мимица-Поповић, објавила 1978. године, у тиражу од 5.000 примерака, издавачка кућа Дечје новине из Горњег Милановца, само шест година након појаве оригинала (La increíble y triste historia de la cándida Eréndira y de su abuela desalmada), истовремено штампаног 1972. године у Латинској Америци (Editorial Sudamericana, Editorial Hermes, Monte Ávila Editores) и Шпанији (Barral Editores).

Neverovatna i tužna istorija nevine Erendire i njene bezdušne babe, друга по реду збирка приповедака која је изашла из пера Габријела Гарсија Маркеса, била је прво дело које је овај аутор објавио пет година после изласка из штампе романа Sto godina samoće (Cien años de soledad). Иако му је поменути роман донео светску славу, Гарсија Маркес је и даље предано неговао приповетку као основни жанр у оквиру којег је практиковао да скицира обрисе сопственог богатог унутрашњег света, примењујући бројне нове, иновативне елементе из својег оригиналног приповедачког поступка. Збирка Neverovatna i tužnaistorija nevine Erendire i njene bezdušne babe, обухвата седам приповедака ${ }^{1}$, насталих у периоду од 1960. до 1972. године, које по доминантним одликама (елементи магичног и натприродног, барокни стил, фантастични амбијент сродан витешким романима) и основним темама (самоћа, смрт) представљају спону између два Гарсија Маркесова романа (Cien años de soledad, 1967; El otoño del patriarca, 1975).

Прво српско издање збирке Neverovatna i tužna istorija nevine Erendire i njene bezdušne babe садржи предговор („Markesova magija“) у којем аутор Милан Влајчић настоји да прикаже ову Гарсија Маркесову антологију у склопу пишчевог целокупног књижевног стваралаштва, те посебну пажњу посвећује ауторовом најпознатијем и најзначајнијем роману (Cien años de soledad), који је наишао на изузе-

1 „Blakaman dobri prodavac čuda“ (“Blacamán el bueno vendedor de milagros”, 1968); „More izgubljenog vremena“ (“El mar del tiempo perdido”, 1961); „Poslednje putovanje avetinjskog broda“ ("El último viaje del buque fantasma”, 1968); „Večita smrt od ljubavi dalja“" ("Muerte constante más allá del amor”, 1970); „Veoma stari gospodin sa ogromnim krilima“ ("Un señor muy viejo con unas alas enormes”, 1968); „Najlepši utopljenik na svetu“ (“El ahogado más hermoso del mundo”, 1968); „Neverovatna i tužna istorija nevine Erendire i njene bezdušne babe" ("La increíble y triste historia de la cándida Eréndira y de su abuela desalmada”, 1972). 
тан пријем широм света захваљујући, пре свега, препорукама читалаца, очараних романескним конгломератом ауторове маште, митских слика, легенди, народних казивања и усмене традиције латиноамеричког континента.

Od maja 1967. godine, kad je ovaj roman prvi put objavljen u Buenos Airesu u skromnom tiražu od osam hiljada primeraka, delo je prevedeno na dvadesetak jezika, donevši Markesu jednodušan glas najvećeg romanopisca Latinske Amerike, dok je veliki i tragički pesnik Pablo Neruda rekao da je Sto godina samoće neuporedivo remek-delo, možda najveće otkriće napisano na španskom jeziku od Servantesovog Don Kihota naovamo. Za ovih desetak godina od prvog objavljivanja, samo na španskom jeziku prodato je više od devet miliona primeraka, a najveće izdavačke kuće na takozvanim velikim jezicima utrkuju se da što brže predstave obiman opus ovog pisca, sa čijim munjevitim prodorom na gotovo sve best-seler liste sveta, i istovremeno u središte pažnje najuglednijih književnih kritičara i znalca, jednostavno ne može ništa da se poredi. Valjda se samo tako može objasniti da je najnoviji Markesov roman Patrijarhova jesen, objavljen početkom 1977. godine, za nepunih šest meseci, preveden na više od trideset jezika!

(Vlajčić, 1978: 8)

Позивајући се на тврдњу француског историчара књижевности Албера Тибодеа (Albert Thibaudet) да у стваралаштву сваког великог писца постоји књига која представља матицу, тј. језгро његове уметности, Милан Влајчић (1978: 9) истиче да у плодној списатељској делатности Габријела Гарсија Маркеса ова улога несумњиво припада роману Sto godina samoće, у којем аутор привидно преузима поступак народног усменог приповедача да би га изнутра деконструисао и удахнуо му многоструке функције модерних наратива, срећно избегавши радикалну концептуализацију језика и његово одвајање од народне говорне традиције. Гарсија Маркесова проза, сва у опојним чулним сликама, спаја поезију, хумор и пародију, без хронолошке развијености у времену, користећи логику сна и фантастичног увек и тамо где треба разобличити трагичну стварност (Vlajčić, 1978: 9). Ослањајући се на мишљење енглеског критичара Аластера Рида (Alastair Reid) o 
конзистентности Гарсија Маркесовог наративног дискурса, Влајчић (1978: 9) истиче да роман Sto godina samoće обједињује стогодишње митове народне свести са крвавим окрутностима друштвеног насиља, а језик постаје средство продорног критичког увида и, силом парадокса истовремено, поетске мистификације стварности.

Збирка Neverovatna i tužna istorija nevine Erendire i njene bezdušne babe, настала из Гарсија Маркесове потребе да превазиђе сопствене креативне тешкоће у започињању новог романа, доноси седам прича, од којих је завршна (уједно и насловна) творевина готово мали пикарски роман, како истиче аутор предговора, док осталих шест остварења условно припадају жанру кратке приче, показујући читаоцима, уз сва препознатљива својства Гарсија Маркесовог приповедачког проседеа, ново лице овог хиспаноамеричког ствараоца:

Posle tako celovite, slojevite i mnogoznačne knjige kao što je Sto godina samoće, bilo je razloga za bojazan da će se Markes u sledećoj knjizi ponavljati, a ne obnavljati. Na svu sreću, dogodilo se ovo drugo. Rukopis je istovetan: bogata, virtuozna, upečatljivim i zamamnim čulnim slikama nabijena rečenica, koja s neverovatnom gipkošću prati izoštrenu i pesnički iskošenu Markesovu percepciju stvari i pojava. Svet iz kojeg Markes crpi ove priče, uslovno govoreći, pripada civilizaciji mitskog Makonda (premda su mesta zbivanja radnje različita i pomaknuta severnije, ka Karibima), s onom istom uslovnošću s kojom se kaže da je Fokner stalno stremio Joknapatafi, a Džojs rodnom a ipak skroz na skroz izmaštanom Dablinu.

(Vlajčić, 1978: 10)

С премисом да се иновативност збирке Neverovatna i tužna istorija nevine Erendire i njene bezdušne babe огледа првенствено у особености заступљених боја и драматургији збивања, Влајчић (1978: 11-12) приступа сажетој анализи свих седам прича: „Blakaman dobri prodavac čuda“", исприповедана у првом лицу, уз обиље претеривања народних казивача, ироније, пародије и фарсе, пружа трагикомичну исповест вашарских превараната, истовремено расветљавајући понешто од Гарсија Маркесове наративне поетике; „More izgubljenog vremena“ прати судбину једног приморског сеоцета уз мноштво нестварних сновиђења и невероватних сањарија, која код читаоца стварају утисак 
вечне лепоте архетипа колективног детињства; „Poslednje putovanje avetinjskog broda“, прича саткана од само једне реченице (у трећем лицу једнине) исписане на шест страница, представља ремек-дело Гарсија Маркесове језичке истанчаности и дотераности приповедачке технике у којем се један догађај описује у двоструком огледалу халуцинантног сновиђења и варљиво опипљиве стварности; „Najlepši utopljenik na svetu“ и „Vrlo stari gospodin sa ogromnim krilima“ имају сродну драматуршку идеју (долазак нечег нестварног и натприродног у средину приземног сеоског таворења), која је остварена мирнијим приповедачким поступком, у маниру најбоље прозе фантастичног жанра, уз неизбежну примену хумора који аутору пружа могућност иронијског и пародијског тумачења, без укидања интерпретације нестварног као саставног дела живота; „Večita smrt od ljubavi dalja“, са неумитно логичном структуром (наговештај смрти у првој реченици и њено остваривање у завршној), највише удаљава Гарсија Маркеса од његове необуздане маште и повремено густог барокног језика; „Neverovatna i tužna istorija nevine Erendire i njene bezdušne babe“, саздана од низа изненадних епизода кроз које пролазе две јунакиње, приказује друштвену слојевитост Латинске Америке преламањем дате стварносне слике кроз поетично-ироничну призму изражајних модела, позајмљених из света како пишчевих личних успомена, тако и народних умотворина и легенди.

На крају предговора, Влајчић (1978: 12) закључује да збирка приповедака Neverovatna i tužna istorija nevine Erendire i njene bezdušne babe можда не садржи све оне политичке конотације присутне у роману Sto godina samoće, али, с обзиром на то да припадају истом матичном сазвежђу, нуди - у Тибодеовом значењу појма - прегршт могућности за нова читања Гарсија Маркесовог наратива.

Дечје новине су објавиле 1979. године друго, поновљено издање збирке Neverovatna i tužna istorija nevine Erendire $i$ njene bezdušne babe; након тринаестогодишње паузе, исти издавач је објавио ово дело још једном (1992. године), такође у преводу Јасне Мимица-Поповић, али под делимично измењеним насловом Neverovatna i tužna priča o nevinoj Erendiri i njenoj bezdušnoj babi. У XXI веку, појавио се нови превод поменуте Гарсија Маркесове збирке приповедака, који је сачинила са шпанског језика Надежда Поповић, а објавио издавач 
Sezam Book из Зрењанина 2012. године под насловом Neverovatna $i$ tužna priča o čednoj Erendiri i njenoj bezdušnoj babi, без пропратних критичких текстова и са тиражем од 2.000 примерака.

\subsection{Oči plavog psa}

Годину дана након иницијалног пробоја, у хоризонт очекивања српских читалаца улази избор Гарсија Маркесових приповедака који је приредила Кринка Видаковић Петров, а објавио београдски издавач Рад 1979. године у виду џепног издања („Reč i misao“, XIV kolo, 346) под насловом Oči plavog psa, у тиражу од 10.000 примерака. Ова књига се састоји од пет приповедака, које су одабране из следеће три Гарсија Маркесове збирке: Oči plavog psa (Ojos de perro azul - три приче) $)^{2}$, Sahrana Velike Mame (Los funerales de la Mamá Grande - једна прича) $)^{3}$ и Neverovatna i tužna istorija nevine Erendire $i$ njene bezdušne babe (једна прича). ${ }^{4}$ Све приповетке из поменутог избора превела је са шпанског језика Кринка Видаковић Петров. Наслов овог посебног издања Oči plavog psa представља превод на српски језик наслова збирке Ojos de perro azul 5 из ране фазе Гарсија Маркесовог књижевног стваралаштва у којој се већ уочавају зачеци његове специфичне наративне поетике како на тематском плану (смрт, пролазност живота, неузвраћена и/или немогућа љубав) тако и у приповедачком поступку (меланхоличан тон, онирична стања, непостојање хомогених временских равни).

2 „Neko dira ove ruže“ (“Alguien desordena esas rosas”); „Noć bukača“ ("La noche de los alcaravanes”); „Monolog Izabele dok posmatra kišu u Makondu“("Monólogo de Isabel viendo llover en Macondo").

3 „Pogreb Velike Mame“ (“Los funerales de la Mamá Grande”).

$4 \quad$ „More izgubljenog vremena“ ("El mar del tiempo perdido”).

5 Збирка Ojos de perro azul обухвата прве приповетке Габријела Гарсија Маркеса, које су излазиле (1947-1952) у дневном листу Espectador из Боготе, као и његове приповетке настале средином прошлог века (1953-1955). Након пиратског издања у Аргентини које се појавило 1972. године, ову збирку су објавила -уз ауторово одобрење- два издавача у Мексику (Secretaría de Obras y Servicios de México, 1973; Editorial Sudamericana, 1974); издање (Plaza\&Janés) које садржи 11 приповедака, штампано 1974. године у Барселони, сматра се коначном верзијом ове збирке. 
Кринка Видаковић Петров је написала поговор („Мašta i snoviđenja") у којем анализира приповетке из избора Oči plavog psa, имајући у виду иновације које ове творевине уносе у приповедачки проседе Габријела Гарсија Маркеса. Такође, ауторка поговора се бави појединим прозним остварењима (приповетке, романи) која заузимају истакнута места у дијахронијском низу целокупног Гарсија Маркесовог стваралаштва, а по одређеним одликама су сродна са приповеткама уврштеним у избор Oči plavog psa.

На почетку поговора, Кринка Видаковић Петров (1979: 59) истиче да је Габријел Гарсија Маркес стекао код нас популарност првенствено својим романом Sto godina samoće, да би се, потом, усредсредила на тумачење Кафкиног утицаја на настанак поменутог Гарсија Маркесовог дела. У кафкијанским причама, реално и фантастично се мешају на чудноват начин, док, с друге стране, Латинска Америка представља континент хиперболичних појава и оштрих контраста, који понекад више подсећају на фантастику него на стварност, сматра Кринка Видаковић Петров (1979: 59-60) и указује на постојање додирне тачке између, на први поглед, некомпатибилног Кафкиног духовног света и једног дела као што је Гарсија Маркесов роман Sto godina samoće:

Granice stvarnosti se usled toga relativizuju i šire da bi obuhvatile sve fikcije koje deluju u njoj i sve realne elemente koji deluju fantastično. A granice između subjektivnog i objektivnog se zamagljuju, pretvarajući se u međuprostor gde oba sveta koegzistiraju. To se jasno manifestuje u jednom detalju Markesovog stvaralaštva: u načinu na koji se obrađuje njegov omiljeni lajtmotiv - smrt. Na neki način ona je uvek živa smrt jer se razvija u svesti umrlih, umirućih i živih (u mašti, snoviđenjima i košmarima).

(Vidaković Petrov, 1979: 60)

У првој приповеци („Neko dira ove ruže“) из избора Oči plavog psa доминира ток свести главних јунака, док приповедање у првом лицу омогућава виши степен субјективизације, а спољна радња се своди на једну статичну ситуацију која се постепено, кроз сећање, осветљава, продубљује и драматизује (Vidaković Petrov, 1979: 60). Ayторка поговора истиче да је утицај Фокнера на Гарсија Маркесово 
усавршавање унутрашњег монолога, посебно видљив у приповеци „Monolog Isabele dok posmatra kišu u Makondu“, где се пажња читалаца креће у кружном току од неког спољашњег догађаја преко субјективног доживљаја ликова до, поново (на крају приче), сагледавања објективног света, те да је Фокнеров утицај још очигледнији у Гарсија Маркесовом првом роману Oharaska (La hojarasca) у којем се унутрашњи монолози протагониста, по угледу на роман тока свести, повезују у јединствени спољни оквир преузет из Анйиїоне (Vidaković Petrov, 1979: 61). Приповетка „Pogreb Velike Mame“ представља индиректну пародију древних јеванђелиста који својом речју сведоче о невероватним догађајима у животу невероватних личности, закључује Кринка Видаковић Петров (1979: 62-63), док је у неким другим творевинама из исто насловљене Гарсија Маркесове збирке веома наглашена иронија (,Montijelova udovica“) и хумор својствен трагикомедији која се одиграва у Маконду („Dan posle subote“). Приповетка „More izgubljenog vremena“ садржи елементе (мотив дављеника, лик господина Херберта) који се јављају у још неким Гарсија Маркесовим причама (,Poslednja plovidba avetinjskog broda“, „Neverovatna i tužna priča o naivnoj Erendiri i njenoj bezdušnoj babi““, „Najlepši utopljenik na svetu“) и романима (Jesen patrijarha, Sto godina samoće) указује Кринка Видаковић Петров (1979: 64-65), анализирајући њихову међусобну повезаност.

Makondo se kao fiktivni mikrokosmos konstituiše razradom likova koji se provlače iz jedne priče u drugu, pomerajući se iz prvog plana u pozadinu, i obratno; tako da je pisac pri razradi ovog romana imao već galeriju formiranih primarnih i sekundarnih likova (Velika Mama, pukovnik Aurelijano Buendija, pop Antonio Isabel, Magdalena, predsednik opštine itd.) i jasnu sliku Makonda, u kojem će se odigravati složena priča o usponu i padu jedne porodice i jednog kontinenta - Latinske Amerike - u skladu $\mathrm{s}$ istorijom, ali i sa mitom.

(Vidaković Petrov, 1979: 64)

Приповедање којем је својствено сједињавање разнородних елемената (приповедачки описи, говор ликова, унутрашњи монолози) у готово непрекидни реченични ток, нарочито је развијено у причи „Poslednja plovidba avetinjskog broda“" и роману Jesen patrijarha, истиче 
Кринка Видаковић Петров (1979: 65), док у причи-новели „Neverovatna i tužna priča o naivnoj Erendiri i njenoj bezdušnoj babi“ Гарсија Маркес користи обрасце и мотиве преузете из нереалистичке традиције, које потом трансформише и вешто комбинује у нове наративне целине:

U toj tragikomediji učestvuju svi Markesovi tipizirani likovi - slični klovnovima ili likovima iz komičnih nemih filmova: predsednik opštine, vojska, političari, muzikanti, šverceri, kaluđeri, makroi, itd. Svi uzori (mitski, hagiografski i oni izvedeni iz viteških romana) kao aveti se spuštaju u cirkuski kontekst, gde se pretvaraju u maske iza kojih izviruje stvarnost. A priču pokreće Markesov simbolični vetar, koji će na kraju - kao neki čarobni štapić - izbrisati sve opipljive tragove Erendirine sudbine.

(Vidaković Petrov, 1979: 66)

На крају поговора, Кринка Видаковић Петров (1979: 66) сагледава роман Jesen patrijarha, који је настао после збирке Neverovatna $i$ tužna priča o naivnoj Erendiri i njenoj bezdušnoj babi, као сублимацију дотадашњег Гарсија Маркесовог стваралаштва, односно, као поему у прози, исписану на 450 страна, у којој се аутор субјективизацијом и лиризацијом приповедања враћа психолошком роману, уз сва искуства већ стечена применом пародије и ироније у претходно написаним приповеткама.

Markesova proza razvija se kao ispitivanje različitih vidova fantastike koja se javlja s obe strane ogledala: kao sastavni element stvarnosti (niz delimično hiperbolizovanih i kontrastnih pojava); kao element koji se odvaja i udaljava od stvarnosti (u vidu njene subjektivne interpretacije); kao svet konstituisan izvan i iznad stvarnosti (mit, natprirodno); najzad, kao privid koji se postavlja u oštru opoziciju prema stvarnosti (maska). Na tom putu pisac polazi od tragedije, da bi preko melodrame stigao do komedije i završio sa satirom - zatvarajući krug i na tom planu.

(Vidaković Petrov, 1979: 67)

Издавачка кућа Рад је објавила 1980. године друго, поновљено, џепно издање избора Oči plavog psa (,Reč i misao“, XIV kolo, knjiga 
346), а, потом, 1999. године и треће издање поменутог избора, такође у оквиру џепне библиотеке „Reč i misao“ (Jubilarno kolo, knjiga 346), допуњено приповетком „Neverovatna i tužna priča o naivnoj Erendiri i njenoj bezdušnoj babi““, коју је, такође, превела са шпанског језика Кринка Видаковић Петров.

Верзија Гарсија Маркесове збирке Oči plavog psa са једанаест приповедака (чији оригинал потиче из 1974. године) ${ }^{6}$, појавила се код нас тек 1992. године у издању Дечјих новина и преводу са шпанског језика Маше Рајчић и Браниславе Домић, са тиражем од 3.000 примерака и без икаквих пропратних критичких текстова.

Средином друге деценије XXI века, издавач Sezam Book je објавио проширену варијанту збирке Oči plavog psa, састављену од четрнаест приповедака ${ }^{7}$, које је превела са шпанског језика Силвија

6 Ojos de perro azul (Barcelona, Plaza\&Janés, 1974): „,Treće mirenje sa sudbinom“ (“La tercera resignación”); „Druga strana smrti“ (“La otra costilla de la muerte”); „Eva je u svom mačku“ (“Eva está dentro de su gato”); „Gorčina za tri mesečara“ (“Amargura para tres sonámbulos”); „Dijalog u ogledalu“ (“Diálogo del espejo”); „Oči plavog psa“ (“Ojos de perro azul”); ,Žena koja je dolazila u šest" ("La mujer que llegaba a las seis”); „Nabo, crnac koga su čekali anđeli“ (“Nabo, el negro que hizo esperar a los ángeles”); „Neko pomera ruže“ (“Alguien desordena esas rosas”); „Noć bukača“ ("La noche de los alcaravanes”); „Isabelin monolog dok posmatra kišu u Makondu“ ("Monólogo de Isabel viendo llover en Macondo").

7 Поводом педесетогодишњице од изласка из штампе прве Гарсија Маркесове приповетке (“La tercera resignación”, 1947), издавач Plaza\&Janés je објавио 1997. године ново, проширено издање збирке Ojos de perro azul у које је уврстио још три приповетке колумбијског писца: „Tubal-Kajinkuje jednu zvezdu“ (“Tubal-Caín forja una estrella”), трећу приповетку Габријела Гарсија Маркеса, која је први пут објављена 17. јануара 1948. године у књижевном додатку колумбијског дневног листа Espectador (Gilard, 1997: 179-180); „О tome kako Natanael ide u posetu“ ("De cómo Natanael hace una visita”), седму Гарсија Маркесову приповетку, објављену први пут 6. маја 1950. године у часопису Crónica, за коју се након тога сматрало да је изгубљена све док поново није изашла 4. јуна 1978. године у листу Espectador (Zuluaga Osorio, 2015: 9) и „Čovek dolazi po kiši“ (“Un hombre viene bajo la lluvia”), приповетку објављену 1954. године у листу Espectador (Banrepcultural, 2018). Поред ових, додатих приповедака, издање збирке Ojos de perro azul из 1997. године обухвата и комплетан корпус издања из 1974. године, који чини једанаест приповедака: „Treće mirenje sa sudbinom“ (“La tercera resignación”, 1947); „Eva je u svojoj mački“ ("Eva está dentro de su gato”, 1948); „Drugo rebro smrti“" ("La otra costilla de la muerte”, 1948); „Dijalog ogledala“ (“Diálogo del espejo”, 1949); „Jed 
Монрос Стојаковић. Иако су се код нас током XX века већ била појавила четири издања са овим насловом, издање из 2015. године (штампано у тиражу од 2.000 примерака), утицало је квалитативно на промену видокруга очекивања српских читалаца, на шта скреће пажњу и Силвија Монрос Стојаковићу пропратном тексту („Tako se kalila mašta: umesto pogovora“"):

[...] zanimljivo je da u ranijim prevodima ove knjige na srpski nema uvek naslovne priče. Ali zato se pod istim naslovom u tim izdanjima pojavljuje i priča o Erendiri i njenoj bezdušnoj babi. Iako je ona napisana dvadesetak godina kasnije i ona se, uglavnom, svuda u svetu objavljuje kao samostalno delo, pa čak i kod nas.

(Monros Stojaković, 2015: 119)

Приповетке из почетне фазе Гарсија Маркесовог стваралаштва представљале су, по речима самог аутора, видове тражења стварности усред нестварности, истиче Монрос Стојаковић (2015: 120), наводећи писце (Вирџинија Вулф, Кафка, Фокнер, надреалисти) који су особито утицали на књижевно формирање будућег колумбијског нобеловца. Узимајући у обзир да Гарсија Маркес својим првим приповедачким покушајима растерује сопствени страх од писања тако што у њих уграђује цео репертоар клиничке патологије, учестало помињући смрт, умирање, гробове, црвоточне очи и плутајуће лешеве, Монрос Стојаковић (2015: 121) указује на истовремено присуство хумора у овим његовим творевинама. На крају поговора, нашим читаоцима се скреће пажња на то да је Гарсија Маркесова интерпункција морала да буде саображена српском правопису упркос настојањима преводиоца да у највећој могућој мери сачува аутентичан ауторов рукопис (Monros Stojaković, 2015: 121).

trojice mesečara“ (“Amargura para tres sonámbulos”, 1949); „Oči plavog psa“ (“Ojos de perro azul”, 1955); „Žena koja je stizala u šest“ (“La mujer que llegaba a las seis”, 1959); „Noć barskih šljuka“ (“La noche de los alcaravanes”, 1953); „Neko vršlja među ovim ružama“ (“Alguien desordena estas rosas”, 1952); „Nabo, crnac koji je naterao anđele da čekaju“ ("Nabo, el negro que hizo esperar a los ángeles”, 1951); „Isabelin monolog dok gleda kišu nad Makondom“ ("Monólogo de Isabel viendo llover en Macondo”, 1955). 


\subsection{Sahrana Velike Mame}

Исте 1979. године када је у видокруг наших читалаца ушао избор Oči plavog psa, издавач Дечје новине је објавио збирку Sahrana Velike Mame са осам Гарсија Маркесових прича ${ }^{8}$, које је превела са шпанског језика Јасна Мимица-Поповић. У овим творевинама, користећи бројна, често апсурдна, претеривања (гротеска, сарказам, сатира, хумор, пародија), писац антиципира магични свет Маконда из романа Sto godina samoće. Збирка се појавила први пут на шпанском језику (Los funerales de la Mamá Grande) 1962. године у мексичком граду Халапи (Xalapa) као посебно издање Универзитета у Веракрусу (Universidad Veracruzana), означивши прекретницу не само у Гарсија Маркесовом стваралаштву, већ и у целокупној новој хиспаноамеричкој приповедној књижевности (Castaño Restrepo, 2007: 256). Српска верзија није била употпуњена одговарајућим критичким текстом ни у првом ни у другом, поновљеном издању, које је реализовао исти издавач 1992. године, у тиражу од 3.000 примерака.

\subsection{Izabel gledajući kako pada kiša u Makondu}

Дечје новине су објавиле 1980. године, у виду посебног издања, приповетку Izabel gledajući kako pada kiša u Makondu (Isabel viendo llover en Macondo), коју је Гарсија Маркес написао 1955. године, уносећи иновативне, наративне технике, својствене магичном реализму (фузија фантастичног, иреалног и стварног; интензивна употреба унутрашњег монолога, брисање временских равни). Јасна МимицаПоповић је превела ову приповетку са шпанског језика, као и текст који има функцију поговора („Pripovetke Gabrijela Garsije Markesa ili nezačarani tropi“ $)^{9}$ немачког есејисте и филмског критичара Ернеста Волкенинга (ErnestoVolkening).

8 „Popodnevni odmor utorkom“ (“La siesta del martes”, 1962); ,Jednog od ovih dana“ ("Un día de éstos”, 1962); „U ovom selu nema lopova“ ("En este pueblo no hay ladrones”, 1962); „Čudesno Baltazarovo popodne“ (“La prodigiosa tarde de Baltazar”, 1962); „Montijelova udovica“ (“La viuda de Montiel”, 1962); „Dan posle subote“ (“Un día después del sábado”, 1962); „Veštačke ruže“ ("Rosas artificiales”, 1962); „Sahrana Velike Mame“ (“Los funerales de la Mamá Grande”, 1962).

9 Овај текст Ернеста Волкенинга изашао је на шпанском језику (“Gabriel García Márquez o el trópico desembrujado“) 1963. године у колумбијском часопису Eco. 
На почетку поговора, Волкенинг (1980: 21-24) износи своја опажања поводом књижевних узора (Џојс, Вулф, Фокнер) који се сматрају кључним чиниоцима у обликовању Гарсија Маркесовог наративног дискурса, те истиче да није могуће са сигурношћу потврдити претпостављене утицаје Џемса Џојса и Вирџиније Вулф, док се аналогије, првенствено у тематици, могу успоставити између колумбијског писца и Вилијема Фокнера: обојица испољавају склоност према вечитом враћању на исте апстракције, односно, реконструкцију једне идеално-типичне и сложене стварности оваплоћене у специфичним насељима (Макондо, Јокнапатофа), која истовремено представљају кондензоване слике безбројних, идентичних насеља и тачку ослонца у условима вечите променљивости појава, тј. осовину око које се окрећу сазвежђа њихових приповедачких свемира. Вредновање дела Габријела Гарсија Маркеса треба да се заснива, по мишљењу Ернеста Волкенинга (1980: 24), пре свега, на његовим индивидуалним својствима, а, потом, на сличностима са творевинама других писаца истог порекла и осталих аутора у свету. При томе, неопходно је имати у виду да се тематске сродности често испољавају независно од стилских различитости, те наилазимо на замршене, компликоване, бескрајне Фокнерове реченице које чврсто, попут спирале, омеђују свој објекат, насупрот кратком, прецизном, језгровитом и јасном Гарсија Маркесовом изразу, који код читаоца ствара непосредан утисак да су ствари заиста такве какве јесу у својој бити, а не другачије, наглашава Волкенинг (1980: 25-27), анализирајући приповетку „Popodnevni odmor utorkom“, коју одликује препознатљива Гарсија Маркесова дескриптивна уздржаност, тачност у запажању, штедљивост и сувопарност језика, без стилских орнамената и субјективних лутања.

Ернесто Волкенинг (1980: 27-28) посебно скреће пажњу на европску опсесију Гарсија Маркесовим реализмом као феноменом урођене аутохтоне укорењености, која се развила аналогно, такође увреженом, ставу о тачностима приче у романима Хосеа Антонија Ocopио Лисараса (José Antonio Osorio Lizarazo), указујући на стилске и тематске разлике између ова два колумбијска писца:

Za razliku od Osoria Lisarasa, čije omiljene teme, kao i stilske pojedinosti, otkrivaju čoveka hladne zemlje, prepunog maglovite melanholije visoravni, zaronjenog u sredinu polumanastirskog, 
polubirokratskog grada njegovog detinjstva, Markes predstavlja pripovedača vrele zemlje u specifičnom smislu koji pripisujemo ovom geografskom pojmu.

(Volkening, 1980: 29)

Гарсија Маркесово стваралаштво нераскидиво је повезано са тропским поднебљем како у тематском тако и у погледу специфичног сензибилитета, истиче Волкенинг (1980: 29-31) и додаје да читалац постаје магични учесник у причама овог писца не зато што је привучен њиховом тешко сроченом фабулом, догађајима, дијалозима и/или ликовима, већ због напетости која лежи у некој средишној зони, испуњеној неодређеностима и зачуђујућим тишинама, као што је то случај, на пример, са приповетком „Veštačke ruže“. У том смислу, Гарсија Маркес не само што наставља литерарну традицију Латинске Америке, утемељену у делима Жоакима Марија Машадо де Асиса (Joaquim Maria Machado de Assis), Хосеа Еустасио Ривере (José Eustasio Rivera) и Ромула Гаљегоса (Rómulo Gallegos) којима је својствена доминација природе и пејзажа (непрегледна пространства), већ је новим изражајним средствима доводи до врхунца (ужасна, агресивна врућина; халуцинантни и телесно опипљиви климатски утицаји), истовремено започињући процес свесног ослобођења од утицаја тропског предела, а тиме и процес својеврсне хуманизације (Volkening, 1980: 32-34).

Lišen bujnih vegetacija i hromatičnih bogatstava, tropski svet Garsija Markesa otkriva opustošenost, bedu, bezbojnu prostotu, ispipanu, prašnjavu i nepodnošljivu; ali, sa isto toliko jasnoće, ocrtava profil sela, njegovu sopstvenu golu bedu, viđenu izviđačkim okom uporedivim sa objektivom fotografske kamere; to izaziva čudan osećaj, u isto vreme uzbudljiv i osvajački. Zabeležimo i najvažniji aspekat: kako se smanjuje bujni pejzaž američke novele, kao potkresan ogromnim baštovanskim makazama na skromnije i površinske dimenzije, tako ljudski lik iz pozadine dolazi u prvi plan. Drugim rečima, pripovedač ponovo osvaja teren koji je čovek bio izgubio, u svojoj grozničavoj borbi sa prirodom, i u spoljnoj širini, u čijim se prostranstvima tope čvrsti oblici, i stvara se jedna nova dimenzija, potpuno ljudska, pogodna za razvijanje uspešno ocrtane individualnosti.

(Volkening, 1980: 34-35) 
Иако су Гарсија Маркесови ликови увек изграђени у складу са конкретном и целовитом стварношћу, која је условљена низом друштвено-историјских околности, њихова карактеризација се не исцрпљује искључиво социјалном функцијом, већ обухвата и јасну индивидуалну идентификацију у чијем дефинисању пресудну улогу има пишчев специфичан начин евоцирања беде, сматра Волкенинг (1980: 35-38) и као пример наводи роман Pukovniku nema ko da piše (A coronel no tiene quien le escriba) у којем је стање беде нераскидиво спојено са постојањем пуковника и његове астматичне жене. Протагонисти готово свих Гарсија Маркесових прича личе, по аутору поговора, на пуковника и његову жену: представнике мушког рода одликује неограничена способност да стварају илузије које им омогућавају да саграде сопствени измаштани свет, док су жене носиоци разума, чија снага се огледа у томе да, упркос неповољним околностима у којима се налазе, развију имагинацију и присуство духа:

Ima nečeg prolaznog, klizavog, kapricioznog i neuhvatljivog u ovom svetu muškarca ovladanog voljom, u kojem se, ipak, nedostatak upornosti suprotstavlja njihovom tvrdoglavom naporu da se uhvate - bez obzira na svakodnevne kritičke komentare svesti - za suknje promenljive boginje Sreće. Evo jednog premeštanja centra gravitacije iz muške sfere u žensku, neka vrsta promene uloga u kojoj pisac uživa.

(Volkening, 1980: 40)

Гарсија Маркес не попуњава метафизичку неизвесност насталу након Маконда уобичајеним заменама за губитак интегритета бића, већ примењује фрагментарност у својим приповеткама да би дочарао сопствену визију једног недовршеног света, закључује на крају поговора Ернесто Волкенинг (1980: 43-44).

\subsection{Oharaska i druge priče}

Средином последње деценије XX века, издавачка кућа Дечје новине објавила је (1994. године) компилацију својих претходних издања Гарсија Маркесове фикционалне прозе под заједничким насловом Oharaska i druge priče. Овај избор обухвата кратак роман Oharaska ${ }^{10}$ и три збирке приповедака (Oči plavog psa; Sahrana Velike

\footnotetext{
10 Издавач Дечје новине објавио је Гарсија Маркесов роман Oharaskay обли-
} 
Mame; Neverovatna i tužna priča o nevinoj Erendiri i njenoj bezdušnoj babi). Неуобичајену структуру поменуте књиге оправдава међусобна наратолошка повезаност заступљених Гарсија Маркесових дела; наиме, роман Oharaska пружа проширену слику фиктивне стварности која је већ приказана у приповеци „Isabelin monolog dok posmatra kišu u Makondu“, обрађујући исте мотиве, ликове и амбијент, уз примену препознатљивог приповедачког поступка (кинеске кутије, унутрашњи монолог). Избор Oharaska $i$ druge priče не садржи допунске, критичке текстове; превод са шпанског језика сачиниле су Јасна Мимица, Маша Рајчић и Бранислава Домић, а одштампани тираж износи 1.000 примерака.

\subsection{Dvanaest priča iz tuđine}

Крајем прошлог века, наша читалачка публика је добила прилику 1999. године да се сретне са збирком Dvanaestpriča iz tuđine (Doce cuentos peregrinos), последњом која је изашла из пера Габријела Гарсија Маркеса седам година пре објављивања превода на српски језик. За приповетке из ове збирке, Гарсија Маркес је рекао да су настајале током осамнаест година (1974-1992) несвакидашње стваралачке пракce. „Pre sadašnjeg oblika, pet [priča] su objavljene kao članci u novinama i kao filmski scenariji, a od jedne je napravljena televizijska serija. Ostale sam ispričao pre petnaest godina u snimljenim intervjuima, a prijatelj kome sam ispričao napisao ih je i objavio, a ja sam ih sada ponovo napisao pošavši od te verzije.“" (Garsija Markes, 1999a: 7) Поменутих дванаест прича ${ }^{12}$ су производ многоструких креативних напора, који су у свом крајњем исходишту резултирали, по изјави самог аутора, чином писања из чистог задовољства:

ку посебне публикације два пута $(1978,1992)$.

11 „Srećan put, gospodine predsedniče“ ("Buen viaje, señor Presidente”, 1979); „Svetica“ (“La santa”, 1981); „Avion uspavane lepotice“ (“El avión de la bella durmiente”, 1982); „Iznajmljujem svoje snove“ (“Me alquilo para soñar”, 1980); „Došla sam samo da telefoniram" ("Solo vine a hablar por teléfono”, 1991); „Avgustovski duhovi“ ("Espantos de agosto”, 1980); „Marija dos Praseres“ ("María dos Prazeres”, 1989); „Sedamnaest otrovanih Engleza“ ("Diecisiete ingleses envenenados”, 1980); „Tramontana“ (“Tramontana”, 1982); „Srećno leto gospođe Forbes“ (“El verano feliz de la señora Forbes”, 1981); „Svetlost je kao voda“ (“La luz es como el agua”, 1978); „Trag tvoje krvi na snegu" ("El rastro de tu sangre en la nieve", 1981). 
Pored toga što sam radio istovremeno na svim pričama $\mathrm{i}$ skačući s jedne na drugu potpuno slobodno, dobio sam panoramski pogled koji mi je omogućio da pobegnem od zamora uzastopnih početaka i pomogao mi je da eliminišem lenčarenje i smrtonosne kontradikcije. Verujem da sam tako dobio knjigu pripovetki najbližu onoj koju sam oduvek hteo da napišem.

(Garsija Markes, 1999a: 12)

Збирку Dvanaest priča iz tuđine превела је са шпанског језика Валерија Пор, а објавиле су Дечје новине, без пратећих критичких текстова. Прво издање на шпанском језику изашло је 1992. године, захваљујући здруженој активности различитих издавача, истовремено у Боготи (Oveja Negra), Мексику (Diana), Буенос Ajpecy (Editorial Sudamericana) и Мадриду (Mondadori).

\section{3. Закључак}

Целокупан Гарсија Маркесов приповедачки опус је преведен са шпанског на српски језик са флуктуирајућом временском дистанцом (7-17 година), што указује на реализацију одговарајуће преводне рецепције у потпуности, али уз појаву приметне реверзибилности у почетној фази, када је дошло до темпоралног одступања у пријему појединих збирки у односу на хронолошки след њиховог појављивања на шпанском језику. У овом рецепционистичком процесу, дугом непуне четири деценије (1978-2015), изашло је укупно четрнаест посебних издања на српском језику у целости посвећених Гарсија Маркесовим приповеткама. Иницијални пробој хоризонта очекивања наших читалаца остварен је када су Дечје новине из Горњег Милановца објавиле 1978. године збирку Neverovatna i tužna istorija nevine Erendire i njene bezdušne babe у преводу са шпанског језика Јасне Мимица-Поповић. Током првих двадесетак година испитаног раздобља (1978-1999), појавила су се прва српска издања све четири Гарсија Маркесове збирке приповедака (Neverovatna i tužna istorija nevine Erendire i njene bezdušne babe, 1978; Oči plavog psa,1979; Sahrana Velike Mame, 1979; Dvanaest priča iz tuđine, 1999). Преводну рецепцију приповедне прозе Габријела Гарсија Маркеса на српском језику одликује уједначено смењивање (два) прекида у трајању од десет година (1981-1991; 2000-2011) и (три) периода 
учесталих пробоја хоризонта очекивања наших читалаца (1978-1980: 6 издања; 1992-1999: 6 издања; 2012-2015: 2 издања), током којих се по интензитету објављивања (3 издања) издвајају две године $(1979,1992)$.

У превођењу Гарсија Маркесових приповедака са шпанског на српски језик учествовало је седам преводилаца (Јасна Мимица-Поповић, Кринка Видаковић Петров, Маша Рајчић, Бранислава Домић, Валерија Пор, Силвија Монрос Стојаковић, Надежда Поповић) и три издавачке куће: Дечје новине из Горњег Милановца, са највише (девет) издања, београдски Рад (3 издања) и Sezam Book из Зрењанина, који се бавио овим видом рецепције у XXI веку (2 издања). Највише издања су имале збирке Oči plavog psa (пет) и Neverovatna i tužna istorija nevine Erendire i njene bezdušne babe (четири). Збирка Oči plavog psa преведена је код нас три пута: једном парцијално (Кринка Видаковић Петров, 1979) и два пута у целости (Маша Рајчић и Бранислава Домић, 1992; Силвија Монрос Стојаковић, 2015). Збирка Neverovatna i tužna istorija nevine Erendire i njene bezdušne babe има две варијанте превода на српски језик (Јасна Мимица-Поповић, 1978; Надежда Поповић, 2012). Српски преводи приповедака Габријела Гарсија Маркеса били су пропраћени, у већини случајева, одговарајућим текстовима (предговори, поговори) чији су аутори неретко били преводиоци (Кринка Видаковић Петров, Силвија Монрос Стојаковић) или, у другим случајевима, домаћи и страни критичари (Милан Влајчић, Ернесто Волкенинг). Тиражи у којима су одштампане збирке Гарсија Маркесових приповедака на српском језику варирали су од 5.000 примерака за издања из XX века до 1.000 примерака за издања из XXI века.

Приповетке Габријела Гарсија Маркеса, сабране у четири збирке током друге половине XX века, имају изузетну литерарну вредност како у оквиру пишчеве књижевне заоставштине тако и у склопу хиспаноамеричке књижевности, јер одражавају ауторово уметничко сазревање почев од његове младалачке потраге за жељеним изразом до уобличене поетике магичног реализма. Стога, преводи ових приповедака на српски језик значајно доприносе ширењу хоризонта очекивања наших читалаца, а будуће, нове варијанте превода поменутих творевина колумбијског добитника Нобелове награде за књижевност 1982. године, обогатиће већ добро формиран укус читалачке публике у Србији. 


\section{ЛИТЕРАТУРА}

Castaño Restrepo, G. (2007) Cultura popular, oralidad y literatura en "Los funerales de la Mamá Grande". Anales de Literatura Hispanoamericana, 36, 255-268.

Vázquez, M. ${ }^{\mathrm{a}}$ A. La realidad en cubierta. Centro Virtual Cervantes. [on-line] Доступно преко:

https://cvc.cervantes.es/actcult/garcia_marquez/obra/cuentos/ realidad.htm (29.8.2019)

Vidaković Petrov, K. (1979). Mašta i snoviđenja. U G. Garsija Markes, Oči plavog psa (str. 59-67). Beograd: Rad.

Vlajčić, M. (1978). Markesova magija. U G. Garsija Markes, Neverovatna i tužna priča o nevinoj Erendiri i njenoj bezdušnoj babi (str. 7-12). Gornji Milanovac: Dečje novine.

Volkening, E. (1980). Pripovetke Gabrijela Garsije Markesa ili nezačarani tropi. U G. Garsija Markes, Izabel gledajući kako pada kiša u Makondu (str. 21-44). Gornji Milanovac: Dečje novine.

Gilard, J. (1997). El tercer cuento de García Márquez. Caravelle, 67, 179190. [on-line]

Доступно преко:

https://www.persee.fr/doc/carav_1147-6753_1996 num_67_1_2721 (06.9.2019)

Дицков, В. (2016). Хисианоамеричка књижевности: оg йосиимоgернизма gо йосишбма. Београд: Филолошки факултет.

Zuluaga Osorio, C. (2015). Leer a García Márquez. Bogotá: Universidad de Los Andes.

Monros Stojković, S. (2015). Tako se kalila mašta: umesto pogovora. U G. Garsija Markes, Oči plavog psa (str. 119-121). Zrenjanin: Sezam Book.

Originales e inéditos de Gabriel García Márques en el nuevo archivo del Banco de la República. Banrepcultural. Red Cultural del Banco de la República en Colombia. 2018. [on-line]

Доступно преко: http://www.banrepcultural.org/noticias/originalese-ineditos-de-gabriel-garcia-marquez-en-el-nuevo-archivo-debanco-de-la (06.9.2019) 
Pavlović-Samurović, Lj. (1993). Leksikon hispanoameričke književnosti. Beograd: Savremena administracija.

\section{Извори}

Garsija Markes, G. (1978). Neverovatna i tužna istorija nevine Erendire $i$ njene bezdušne babe: sedam priča. Gornji Milanovac: Dečje novine. Garsija Markes, G. (1979a). Neverovatna i tužna istorija nevine Erendire i njene bezdušne babe: sedam priča. 2. izdanje. Gornji Milanovac: Dečje novine.

Garsija Markes, G. (1979b). Oči plavog psa. Beograd: Rad.

Garsija Markes, G. (1979c). Sahrana Velike Mame. Osam priča. Gornji Milanovac: Dečje novine.

Garsija Markes, G. (1980a). Izabel gledajući kako pada kiša u Makondu. Gornji Milanovac: Dečje novine.

Garsija Markes, G. (1980b). Oči plavog psa. 2. izdanje. Beograd: Rad.

Garsija Markes, G. (1992a). Neverovatna i tužna priča o nevinoj Erendiri i njenoj bezdušnoj babi. Gornji Milanovac: Dečje novine.

Garsija Markes, G. (1992b). Oči plavog psa. Gornji Milanovac: Dečje novine.

Garsija Markes, G. (1992c). Sahrana Velike Mame. Gornji Milanovac: Dečje novine.

Garsija Markes, G. (1994). Oharaska i druge priče. Gornji Milanovac: Dečje novine.

Garsija Markes, G. (1999a). Dvanaest priča iz tuđine. 1. izdanje. Gornji Milanovac: Dečje novine.

Garsija Markes, G. (1999b). Oči plavog psa. Beograd: Rad.

Garsija Markes, G. (2012). Neverovatna i tužna priča o čednoj Erendiri $i$ njenoj bezdušnoj babi. Zrenjanin: Sezam Book.

Garsija Markes, G. (2015). Oči plavog psa. Zrenjanin: Sezam Book. 


\title{
Vesna Z. Dickov
}

\section{LA RECEPCIÓN DE LAS TRADUCCIONES DE LAS ANTOLOGÍAS DE CUENTOS DE GABRIEL GARCÍA MÁRQUEZ EN EL IDIOMA SERBIO}

\begin{abstract}
Resumen
Este artículo trata de la acogida de las traducciones de cuentos del escritor colombiano Gabriel García Márquez al serbio, durante el siglo XX y principios del XXI. Con el fin de revisar exhaustivamente los parámetros relevantes y los participantes del proceso de recepción mencionado, se investiga un corpus conformado por las ediciones dedicadas íntegramente a las traducciones de cuentos de García Márquez al idioma serbio; por su parte, las traducciones aparecidas en publicaciones periódicas y antologías de cuentos de varios autores no son objeto de estudio en este trabajo. Tampoco damos un análisis filológico ni interpretación alguna de esta clase de las obras traducidas consideradas. Se presta especial atención al impacto de las traducciones de la cuentística de García Márquez en la formación del horizonte de expectativas de nuestros lectores con respecto a la recepción del realismo mágico y la literatura hispanoamericana contemporánea en Serbia.

Palabras clave: Gabriel García Márquez, cuentos, traducciones, literatura colombiana, literatura hispanoamericana, recepción.
\end{abstract}

